\title{
Pembuatan Motion Graphic Penanganan Pascapanen dan Teknologi Hasil Olahan Cabai di Balai Besar Pascapanen
}

\author{
Sofiyanti Indriasari ${ }^{1,}$ Sendhy Pratama Putra ${ }^{2}$, Evi Savitri ${ }^{3}$ \\ ${ }^{1,2}$ Manajemen Informatika Sekolah Vokasi IPB, Jl. Kumbang No. 14, Bogor \\ ${ }^{3}$ Balai Besar Penelitian dan Pengembangan Pascapanen Pertanian. Jl. Tentara Pelajar No. 12, Bogor \\ sofiyanti@apps.ipb.ac.id,sendhyp@gmail.com, evi.savitri1601@gmail.com
}

Diterima : 10 Mei 2021. Disetujui : 25 Juni 2021. Dipublikasikan : 26 Juni 2021.

\begin{abstract}
Balai Besar Pascapanen is a working unit of the Agricultural Research and Development Agency in charge of carrying out research and development of agricultural post-harvest technology as well as the utilization of agricultural postharvest products such as research in processing chili peppers into chili powder, chili oil, and chili paste. BB Pascapanen has produced many processed chili peppers from agricultural products that have high quality and selling power that are much in demand by the public. The information published today is only through websites and leaflets, so many people do not yet know the information contained in BB Pascapanen. One of its efforts is by making motion graphics that display the process of postharvest handling technology and post-harvest technology for processed chili peppers. The creation of this motion graphic is one of many efforts in the dissemination of information and promotional media of BB Pascapanen. The method used in the creation of motion graphics through seven stages. These stages include discussion, planning, material collection, implementation, testing, revision and distribution. Based on the tests that have been carried out, it can be concluded that the media delivery for information related to post-harvest handling and technology for processed chili peppers using motion graphics become the choice for the public among millennials.
\end{abstract}

Keywords: BB Pascapanen, chili, handling, motion graphics, post-harvest.

Abstrak- Balai Besar Pascapanen merupakan unit kerja Badan Penelitian dan Pengembangan Pertanian yang bertugas untuk melaksanakan penelitian dan pengembangan teknologi pascapanen pertanian serta pendayagunaan hasil pertanian pascapanen pertanian seperti penelitian pengolahan hasil olahan cabai menjadi bubuk cabai, minyak cabai, dan pasta cabai. BB Pascapanen telah menghasilkan banyak olahan cabai dari hasil pertanian yang memiliki mutu tinggi dan daya jual yang banyak diminati masyarakat. Informasi yang dipublikasikan saat ini hanya melalui website dan leaflet, sehingga banyak masyarakat belum mengetahui informasi yang ada di BB Pascapanen. Salah satu upayanya adalah dengan pembuatan motion graphic yang menampilkan proses teknologi penanganan pascapanen dan proses teknologi hasil olahan cabai. Pembuatan motion graphic ini merupakan salah satu upaya dalam penyebaran informasi dan media promosi BB Pascapanen. Metode yang digunakan dalam pembuatan motion graphic melalui tujuh tahapan. Tahapan-tahapan tersebut antara lain diskusi, perencanaan, pengumpulan bahan, implementasi, pengujian, revisi dan distribusi. Berdasarkan pada pengujian yang sudah dilakukan dapat disimpulkan bahwa media penyampaian informasi terkait penanganan pascapanen dan teknologi hasil olahan cabai menggunakan motion graphic menjadi pilihan masyarakat di kalangan milenial.

Kata kunci: BB Pascapanen, cabai, motion graphic, metode, penanganan, pascapanen.

\section{PENDAHULUAN}

Balai Besar (BB) Pascapanen telah menghasilkan banyak teknologi olahan cabai dari hasil pertanian yang memiliki mutu tinggi dan daya jual yang banyak diminati masyarakat. Hal tersebut tidak lepas dari proses penanganan pascapanen yang baik dan benar. Proses penanganan pascapanen dilakukan dengan tujuan mendapatkan kualitas dan jumlah hasil panen yang optimal dan tidak mengalami penurunan. Informasi penanganan pascapanen dan teknologi olahan cabai saat ini hanya dipublikasikan melalui website dan leaflet dalam bentuk tulisan dan gambar. Media publikasi tersebut masih kurang menarik untuk dipelajari masyarakat dan memiliki keterbatasan pada penyebarannya. Media publikasi yang efektif digunakan pada era teknologi berkembang seperti saat ini adalah media yang memiliki kaitan erat dengan 
teknologi seperti gadget, televisi, dan komputer [1]. Komputer sudah banyak diaplikasikan dalam berbagai bidang, tidak terkecuali dalam bidang pendidikan dalam hal ini adalah edukasi kepada masyarakat. Media edukasi berbasis komputer saat ini menjadi salah satu alternatif media yang bisa dipilih karena menawarkan begitu banyak kemudahan diantaranya desain yang menarik dan dinamis. Media ini juga menyediakan grafis serta animasi dan menyediakan fasilitas untuk animasi video dan suara dengan kreasi sendiri atau memanfaatkan yang sudah tersedia [2]. Hasil edukasi yang diajar dengan menggunakan media audio-visual memiliki skor jauh lebih tinggi dibanding dengan yang diajar menggunakan pendekatan konvensional [3]. Media edukasi khususnya sosialisasi meluas di dunia maya, yaitu melalui media sosial. Oleh karena itu, perlu dibuat suatu media informasi yang menarik dan dan informatif serta ringan untuk ditayangkan di media sosial.

Salah satu teknologi multimedia yang dapat dipilih adalah animasi melalui motion graphic dengan durasi pendek tapi menarik untuk ditayangkan di media sosial. Motion graphic adalah teks, gambar, atau kombinasi dari keduanya yang bergerak dalam ruang dan waktu, menggunakan pergerakan dan ritme untuk mengkomunikasikannya [4]. Menurut [5], motion graphic merupakan gabungan dari potongan elemen-elemen desain atau animasi yang berbasis pada media visual yang menggabungkan bahasa film dengan desain grafis, dengan memasukkan elemen yang berbeda-beda seperti elemen 2 dimensi atau 3 dimensi. Pembuatan motion graphic yang memuat penjelasan terkait proses teknologi penanganan pascapanen cabai dan proses teknologi hasil olahan cabai merupakan salah satu upaya dalam penyebaran informasi dan media promosi BB Pascapanen kepada masyarakat sehingga tertarik untuk belajar dan mengenal lebih banyak tentang pascapanen pertanian.

Tujuan dari pembuatan produk multimedia motion graphic di BB Pascapanen adalah menyediakan media penyebaran informasi yang lebih menarik berupa motion graphic tentang Proses Penanganan Pascapanen Cabai dan Proses Teknologi Hasil Olahan Cabai. Manfaat dari pembuatan motion graphic ini diharapkan dapat meningkatkan target sosialisasi di kalangan masyarakat terkait dengan peningkatan pengetahuan tentang proses penanganan pascapanern dan hasil olahan cabai. Target sosialisasi adalah masyarakat millennial yang terbiasa dengan penggunaan teknologi.

\section{METODE PENELITIAN}

Metode yang digunakan dalam pembuatan motion graphic yaitu melalui tujuh tahapan. Tahapan tersebut adalah diskusi, perencanaan, pengumpulan bahan, implementasi, pengujian, revisi, dan distribusi. Tahapan pembuatan motion graphic dapat dilihat pada Gambar 1. Tahapan ini dikerjakan secara berurutan, dan apabila terdapat revisi maka proses pembuatan dapat berulang sampai revisi produk multimedia selesai dilakukan dan layak untuk didistribusikan.

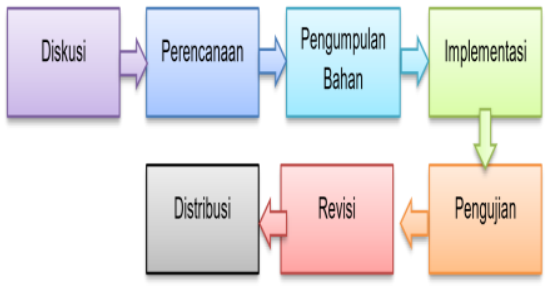

Gambar 1 Tahapan Pembuatan Motion Graphic

\section{A. Diskusi}

Diskusi merupakan proses komunikasi yang dilakukan dengan tujuan untuk mendapatkan kebutuhan suatu proyek. Kebutuhan proyek diinisiasi dengan menentukan terlebih dahulu domain permasalahan yang ingin diselesaikan. Ketika domain permasalahan telah ditentukan maka secara bersamasama mendiskusikan solusi terbaik dan apa saja yang diperlukan untuk mencapai solusi tersebut serta menyepakati ruang lingkup penyelesaian masalah.

Kegiatan diskusi ini juga dilakukan untuk menentukan konsep penyelesaian dan target konsumen. Konsep adalah merumuskan dasar-dasar dari proyek multimedia yang akan dibuat dan dikembangkan seperti tujuan dan jenis proyek [1] Target konsumen dalah hal ini kita sebut sebagai target audience karena kegiatan ini menghasilkan prdouk multimedia. Target audience harus ditentukan agar motion graphic yang dibuat dapat diterima dengan baik berdasarkan kriteria tertentu seperti usia, latar pendidikan, jenis kelamin, dan parameter demografi lainnya. Target audience yang ditetapkan harus sesuai dengan kepribadian kelompok audien seperti umur, hobi, pekerjaan, dan sebagainya [6].

\section{B. Perencanaan}

Tahap perencanaan mempersiapkan semua kebutuhan seperti naskah dan storyboard. Tahap ini dilakukan untuk mempermudah proses implementasi pembuatan motion graphic yang sesuai dengan konsep. Naskah adalah narasi yang merupakan kelengkapan dari penjelasan yang dilihat melalui video 
[7]. Storyboard merupakan sederetan ilustrasi atau gambar yang ditampilkan berurutan untuk keperluan visualisasi awal dari suatu motion graphic [8]. Storyboard merupakan istilah untuk sebuah sketsa awal yang berisi ide cerita, serta susunan-susunan gambar secara lengkap dari setiap adegan [9].

\section{Pengumpulan Bahan}

Tahap pengumpulan bahan berupa data dan referensi, gambar vektor, serta audio sangat diperlukan untuk mempermudah pada tahap implementasi. Data dan referensi digunakan sebagai acuan penyampaian informasi pada motion graphic. Gambar vektor berisi deskripsi geometri yang dapat di-render dengan halus pada ukuran tampilan yang diinginkan [8]. Audio adalah suara dalam bentuk seperti suara, musik, narasi dan sebagainya yang bisa didengar [4].

\section{Implementasi}

Tahap implementasi merupakan proses pembuatan motion graphic menggunakan perangkat lunak multimedia. Implementasi produk motion graphic adalah mewujudkan rancangan storyboard yang telah dibuat menjadi bentuk scene yang merupakan perpaduan elemen-elemen multimedia dan kemudian dianimasikan. Tahap awal dilakukan pengolahan gambar vektor menggunakan Adobe Illustrator CC 2017. Gambar vektor yang sudah siap akan dilakukan penggerakan, pemberian efek khusus, penambahan sound effect, rendering pada Adobe After Effect CC 2017. Selanjutnya, dilakukan penambahan voice over dan backsound, kemudian dilakukan rendering pada Adobe Premiere Pro CC 2017. Rendering adalah mengubah file projek dari menjadi file yang siap dijalankan menggunakan aplikasi media player.

\section{E. Pengujian}

Tahap pengujian dilakukan untuk mengetahui kelayakan motion graphic yang dibuat. Tahap ini melalui dua pengujian, yaitu pengujian alpha dan pengujian beta. Pengujian alpha dilakukan pada tahap construction sedangkan tahap pengujian Beta dilakukan pada tahap deployment [10]. Pengujian alpha dilakukan dengan cara mempresentasikan motion graphic kepada mitra kerjasama dan sesame tim pengembang. Pengujian beta dilakukan dengan menunjukkan produk multimedia yang sudah untuk disaksikan oleh target audience dan kemudian menyebarkan kuesioner yang berisi pertanyaan tentang motion graphic untuk diisi oleh target audience setelah melihat produknya.

\section{F. Revisi}

Pada tahap ini dilakukan perbaikan jika terdapat kekurangan dalam penyampaian informasi, gambar vektor, dan animasi pada motion graphic. Revisi dilakukan jika ada kekurangan dalam segi informasi, desain maupun animasi sesuai permintaan klien agar informasi bisa lebih dipahami [11].

\section{G. Distribusi}

Motion graphic yang telah direvisi akan didistribusikan kepada BB Pascapanen. Gambar vektor yang digunakan juga didistribusikan dengan tujuan mempermudah keperluan pihak BB Pascapanen apabila ingin menggunakan gambar vektor untuk keperluan pengembangan. Distribusi kepada target audience dilakukan oleh tim BB Pascapanen khususnya kepada masyarakat pertanian.

\section{HASIL DAN PEMBAHASAN}

Tahap ini menjelaskan hasil dari proses pembuatan motion graphic sebagai media informasi di BB Pascapanen yang meliputi tujuh tahapan yaitu diskusi, perencanaan, pengumpulan bahan, implementasi, pengujian, revisi, distribusi.

\section{A. Diskusi}

Diskusi dilakukan dengan pihak BB Pascapanen sebagai mitra kerjasama dalam kegiatan ini. BB Pascapanen telah menentukan domain permasalahan yang ingin diselesaikan, yaitu terkait dengan sosialisasi teknologi olahan cabai yang selama ini hanya disampaikan melalui media website dan media cetak berupa tulisan dan ilustrasi gambar yang minimalis. Kegiatan sosialisasi dengan media tersebut perlu untuk ditingkatkan dengan variasi media lainnya agar penyampaian informasi lebih optimal. BB Pascapanen juga mengungkapkan bahwa sosialiasi terkait teknologi pengolahan cabai hendaknya dapat tersebar luas pada masyarakat milenial dengan harapan mereka adalah masyakat yang produktif, enerjik, dan cepat dalam berinovasi untuk penerapan teknologi.

Berdasarkan pemaparan dari BB Pascapanen, disepakati bahwa media sosialisasi yang perlu diusulkan agar lebih optimal kepada sasaran masayarakat milenial adalah membuat motion graphic. Motion Graphic merupakan media menarik yang juga dapat disebarluaskan di media sosial, dimana masyarakat milenial adalah pengguna aktif media sosial. Tahap selanjutnya setelah menentukan domain permasalahan dan solusi yang diambil adalah membuat konsep dan menetapkan target audience. 


\section{Konsep}

Konsep yang didiskusikan pada motion graphic mengikuti perkembangan generasi milenial, yaitu dengan menampilkan banyak gambar bergerak yang menarik dikemas berupa motion graphic. Motion graphic merupakan media yang menggunakan rekaman video atau teknologi animasi untuk menciptakan ilusi gerak dan biasanya dikombinasikan dengan audio untuk digunakan dalam sebuah output multimedia[12]. Masyarakat diharapkan akan lebih tertarik dan mudah memahami informasi yang disampaikan. Selain itu, diharapkan agar masyarakat mempunyai keinginan untuk belajar proses penanganan pascapanen dan teknologi hasil olahan cabai dengan baik dan benar. Dengan demikian, tujuan dari kegiatan ini adalah membuat motion graphic untuk generasi milenial dalam rangka meningkatkan sosialiasi terkait penanganan pascapanen dan teknologi hasil olahan cabai. Durasi motion graphic yang disepakati adalah antara 2 sampai dengan 3 menit. Produk motion graphic yang dibuat juga harus ringan karena nantinya akan disosialisasikan melalui media sosial.

\section{2. $\quad$ Target Audience}

Target audience yang ditentukan yaitu generasi milenial atau masyarakat yang memiliki usia antara 17 30 tahun. Kriteria yang digunakan untuk menggambarkan bagian tertentu dari populasi adalah mulai anak muda sampai orang dewasa yang memiliki pekerjaan sebagai petani dan atau memiliki bisnis terkait. Target audience tersebut dipilih karena usia tersebut adalah usia produktif dan enerjik. Diharapkan generasi tersebut dapat dengan cepat mewujudkan inovasi dan pengembangan bisnis hasil olahan cabai, sehingga menjadi pelopor masyarakat lainnya untuk berkembang. Produk hasil teknologi olahan cabai merupakan produk yang memiliki nilai tambah yang lebih tinggi dibandingkan dengan menjual bahan mentah cabai saja. Oleh karena itu, ketika masyarakat dapat melakukan pengolahan cabai lebih lanjut diharapkan mendapatkan nilai tambah yang lebih dan dapat meningkatkan kesejahteraan mereka.

\section{B. Perencanaan}

Kumpulan ilustrasi atau gambar diurutkan berdasarkan cerita yang sesuai dengan konsep yang telah ditentukan. Storyboard dibuat kemudian didiskusikan dengan BB Pascapanen. Hasil perencanaan beserta penjelasan tiap scene pada storyboard seperti yang terlihat pada Tabel 1.

TABEL I. STORYBOARD

\begin{tabular}{cll}
\hline Scene & \multicolumn{1}{c}{ Rancangan } & \multicolumn{1}{c}{ Keterangan } \\
\hline 1 & $\begin{array}{l}\text { Scene 1 (Intro) } \\
\text { Durasi: 8 detik } \\
\text { Tampi globe } \\
\text { dunia berotasi } \\
\text { kemudian } \\
\text { bendera } \\
\text { Indonesia. }\end{array}$ \\
$\begin{array}{l}\text { Scene 2 (Intro) } \\
\text { Durasi: 2 detik } \\
\text { ampil karakter } \\
\text { orang sedang } \\
\text { membawa } \\
\text { keranjang berisi } \\
\text { cabai, kemudian } \\
\text { mendapat tepuk } \\
\text { tangan. }\end{array}$
\end{tabular}
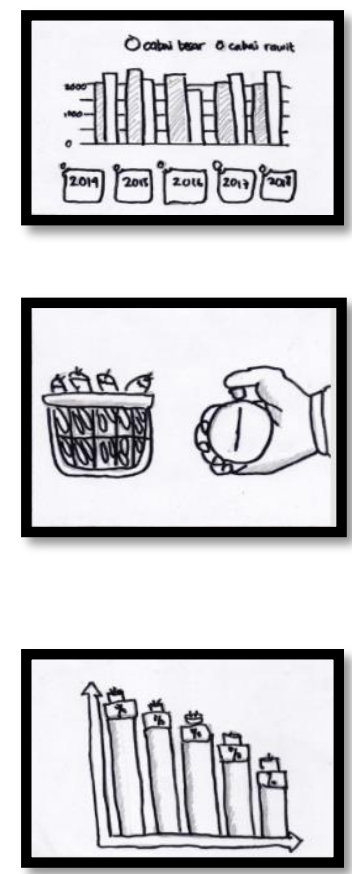

6

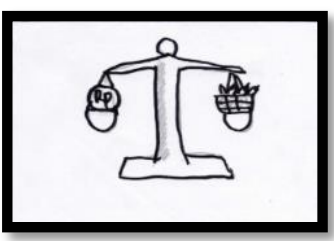

7

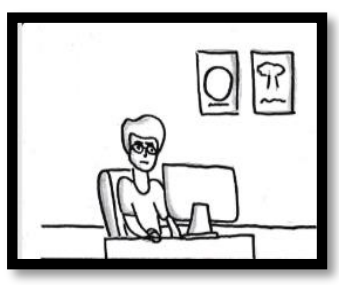

Scene 3

Durasi: 10 detik

Tampil grafik

jumlah hasil

panen cabai

merah dan cabai

rawit dalam 5

tahun terakhir.

Scene 4 (Middle)

Durasi: 9 detik

Tampil

keranjang berisi

cabai yang

mengalami

perubahan pada

warna terhadap

bertambahnya

waktu.

Scene 5

Durasi: 4 detik

Tampil grafik

hasil panen cabai

segar yang

semakin

berkurang.

Scene 6

Durasi: 5 detik

Tampil

timbangan yang lebih berat pada bagian uang.

Scene 7

Durasi: 8 detik

Tampil

karyawan yang sedang bekerja. 


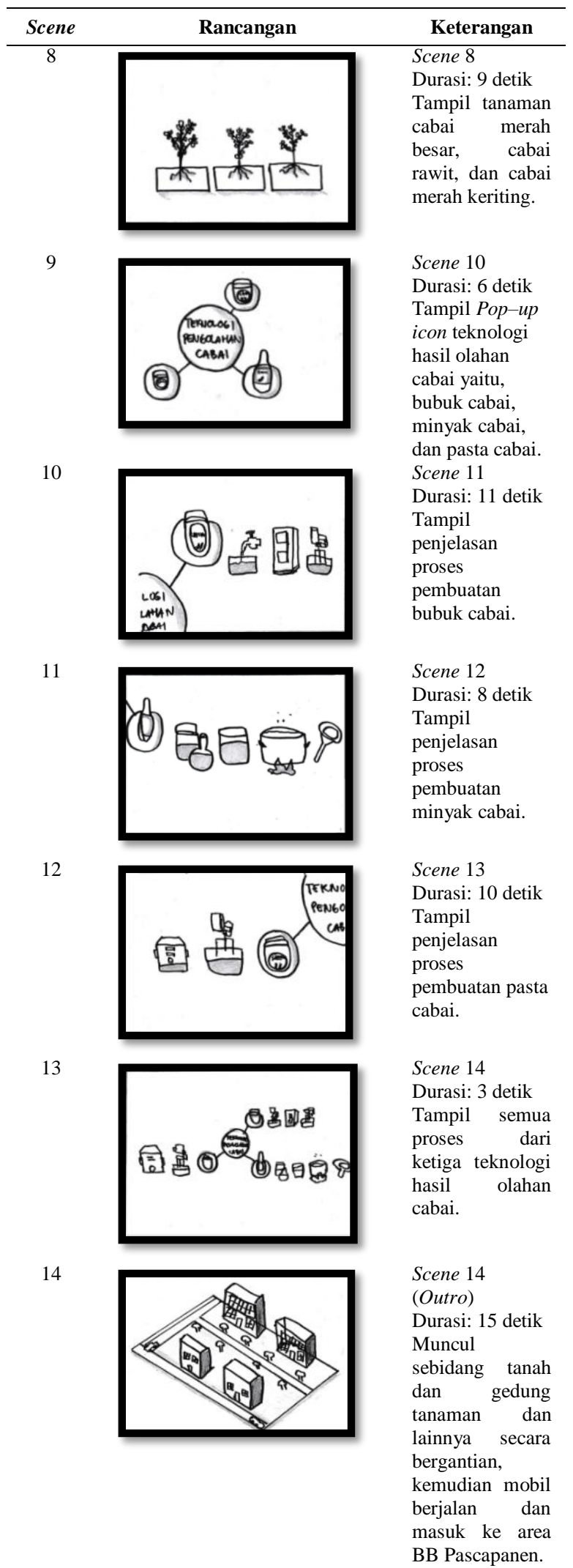

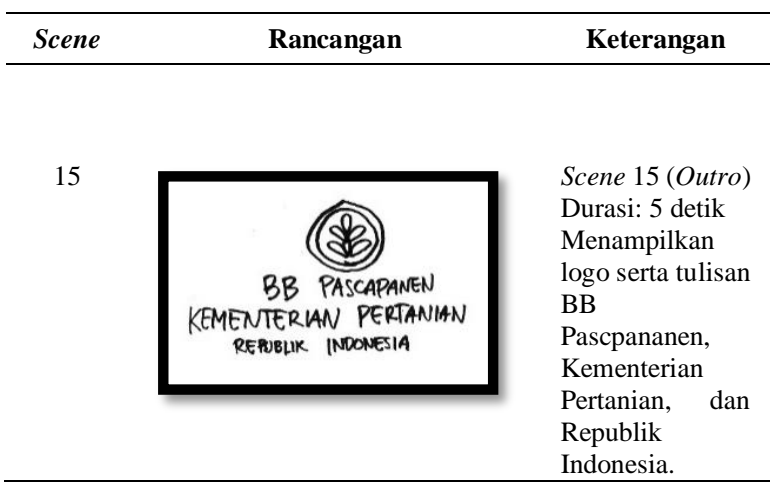

\section{Pengumpulan Bahan}

Data dan bahan untuk pembuatan motion graphic dikumpulkan dari berbagai sumber. Sumber utama berasal dari BB Pascapanen sebagai instansi mitra kerjasama. Pemahaman materi dilihat melalui website dan leaflet yang sebelumnya digunakan oleh BB Pascapanen sebagai media informasi. Berdasarkan hasil diskusi dan perancangan, beberapa gambar vektor perlu disiapkan dan diolah menggunakan Adobe Illustrator CC 2017. Pembuatan gambar vektor pada motion graphic dijelaskan sesuai dengan urutan scene yang terdapat pada storyboard. Selain itu, bahan audio juga dipersiapkan meliputi:

- Sound effect

Sound effect yang digunakan pada motion graphic diperoleh melalui plugin animation composer. Sound effect adalah suara tambahan yang berfungsi menekankan, menggarisbawahi, menghubungkan, menafsirkan gerakan dan menjadi bagian dari pola dramatis sebuah visual dalam film [13]. Sound effect ini digunakan pada pergerakan gambar vektor dan setiap transisi scene.

\section{- Backsound}

Backsound adalah musik atau efek suara yang ditambahkan untuk mendukung suatu pergerakan video atau animasi. Backsound mendukung suatu adegan menjadi lebih menonjol, sehingga konten dalam video tersebut dapat tersampaikan dengan lebih mudah. Backsound dalam pembuatan video animasi sangat berfungsi dikarenakan menambah menariknya video dan tidak membosankan dalam menonton video animasi tersebut [14]. Backsound yang digunakan pada motion graphic ini diperoleh melalui website Youtube dengan lisensi free.

- Voice Over

Voice over adalah narasi tambahan yang berupa suara manusia yang membacakan sebuah 
cerita/narasi yang berkaitan dengan video yang dibuat [15]. Voice Over yang digunakan pada motion graphic dibuat dengan melakukan rekaman suara sesuai dengan narasi. Perekaman suara dilakukan menggunakan handphone. Rancangan urutan narasi untuk mendukung konten produk multimedia tersebut adalah sebagai berikut:

1. Menjelaskan tentang data banyaknya produksi cabai yang dihasilkan di Indonesia dan perkembangannya dari tahun ke tahun.

2. Menjelaskan tentang umur simpan cabai yang tidak lama, dan bahkan cepat rusak jika setelah panen tidak disimpan dengan benar

3. Menjelaskan bahwa nilai cabai tentu akan tinggi jika kualitasnya bagus dan sebaliknya, nilai cabai akan turun jika kualitasnya tidak bagus atau sudah rusak karena penyimpanan yang salah dan terlalu lama (membusuk).

4. Menjelaskan bahwa cabai dapat memiliki nilai tambah jika dilakukan pengolahan lebih lanjut. Selain itu, produk olahan cabai juga dapat lebih tahan lama

5. Menjelaskan jenis-jenis cabai

6. Menjelaskan jenis-jenis produk olahan cabai

7. Menjelaskan tahapan-tahapan teknologi pengolahan cabai hingga menjadi produk olahan cabai yang memiliki nilai tambah lebih tinggi dan lebih tahan lama

\section{Implementasi}

\section{Penggerakan Gambar Vektor}

Penggerakan gambar vektor produk pertama dilakukan menggunakan transform layer properties. Pengaturan yang digunakan pada transform layer properties adalah rotation dan position. Penggerakan gambar vektor dilakukan menggunakan puppet tool. Puppet tool digunakan untuk membuat titik tumpuan pada sebuah gambar vektor yang akan di animasikan serta mempercepat pergerakan animasi secara alami [16].

\section{Pemberian Efek Khusus}

Efek khusus produk pertama yang diberikan pada gambar vektor merupakan efek yang tersedia di Adobe After Effect CC 2017. Efek yang digunakan yaitu CC Slant yang berguna untuk memberikan efek miring pada gambar vektor tanaman cabai agar tanaman terlihat seolah tertiup angin. Efek CC Slant diberikan pada gambar vektor tanaman cabai. Efek khusus produk kedua yang diberikan pada gambar vektor yaitu $C C$ Sphere yang berguna untuk memberikan efek globe pada gambar vektor peta dunia. Efek CC Sphere diberikan pada gambar vektor peta dunia. Implementasi efek CC Sphere pada scene 1.

\section{Penambahan Sound Effect}

Sound effect didapat melalui plugin animation composer. Penambahan sound effect bertujuan untuk memberikan tekanan pada sebuah adegan akan membangun kesan lebih dalam bagi penonton serta memberi arti pada pemunculan atau berakhirnya suatu adegan atau kejadian pada motion graphic.

\section{Rendering Adobe After Effect CC 2017}

Proses render pada Adobe After Effect CC 2017 adalah mengekspor semua file yang terdapat pada composition menjadi satu file video yang berekstensi (avi). Proses render motion graphic penanganan pascapanen cabai dilakukan menggunakan aplikasi Adobe After Effect CC 2017.

\section{Penambahan Voice Over dan Backsound}

Penambahan voice over dan backsound disesuaikan dengan kebutuhan. Penambahan komponen tersebut dilakukan menggunakan Adobe Premiere Pro CC 2017. Voice Over yang ditambahkan merupakan hasil rekaman suara yang membacakan narasi. Backsound ditambahkan dan diselaraskan dengan alur konten animasinya.

\section{Rendering Adobe Premiere Pro CC 2017}

Proses render pada Adobe Premiere Pro CC 2017 adalah mengekspor semua file yang terdapat pada sequence menjadi satu file video yang berekstensi (.mp4). Proses render motion graphic proses penanganan pascapanen cabai pada Adobe Premiere Pro CC 2017. Tabel 2 menunjukkan contoh scene yang telah diimplementasikan.

TABEL II. HASIL IMPLEMENTASI SCENE

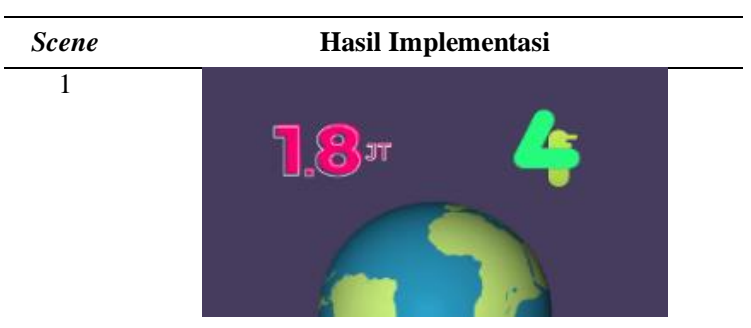




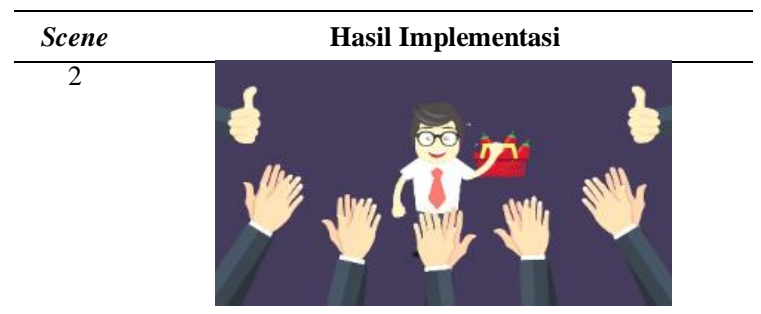

3

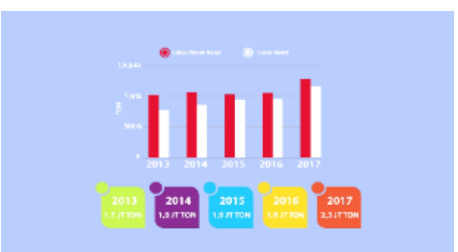

4

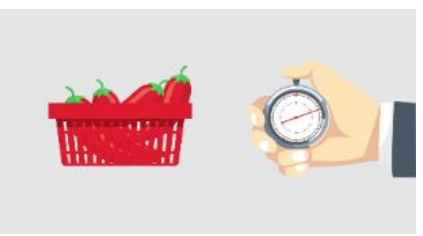

5

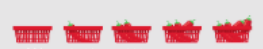$$
\text { (IIII) f IIIIIII }
$$

6

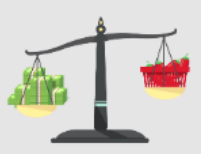

7

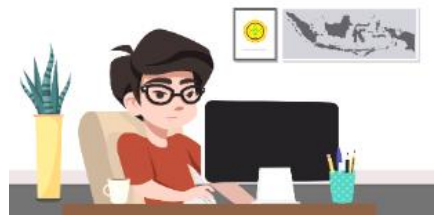

8

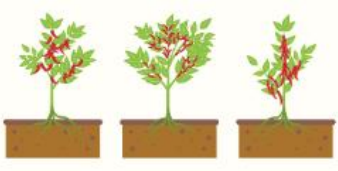

Scene

Hasil Implementasi

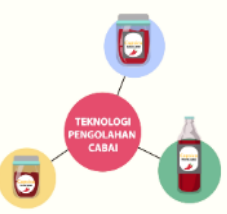

10

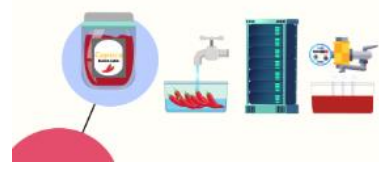

11

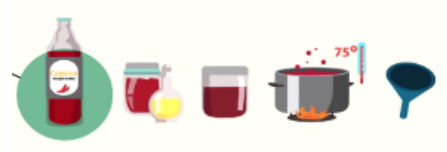

12

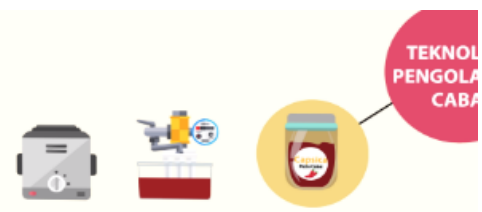

13

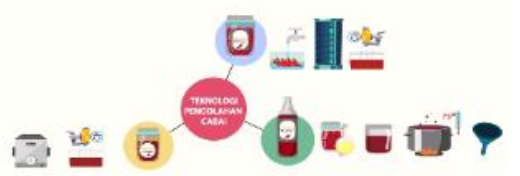

14

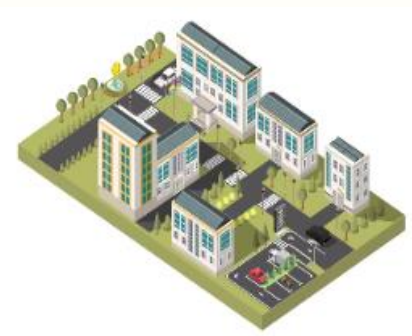

15

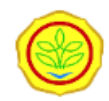

9 


\section{E. Pengujian}

\section{Pengujian Alpha}

Tahap pengujian alpha adalah melakukan presentasi hasil motion graphic kepada instansi BB Pascapanen untuk diberikan kritik dan saran. Berikut hasil pengujian alpha ditunjukkan pada Tabel 3 .

TABEL III. HASIL PENGUJIAN PRODUK

\begin{tabular}{|c|c|c|c|}
\hline No & Penguji & Kritik/ Saran & Tindakan \\
\hline \multirow[t]{2}{*}{1} & BB Pascapanen & $\begin{array}{l}\text { Voice over yang } \\
\text { kurang jernih dan } \\
\text { tempo terlalu cepat. }\end{array}$ & $\begin{array}{l}\text { Voice over telah } \\
\text { diganti dengan } \\
\text { kualitas suara } \\
\text { yang lebih baik } \\
\text { dan tempo yang } \\
\text { sesuai dengan } \\
\text { motion graphic. }\end{array}$ \\
\hline & & $\begin{array}{l}\text { Perlu penambahan } \\
\text { logo Kementerian } \\
\text { Pertanian pada scene } \\
\text { outro. }\end{array}$ & $\begin{array}{l}\text { Telah } \\
\text { ditambahkan logo } \\
\text { Kementerian } \\
\text { Pertanian dalam } \\
\text { scene outro }\end{array}$ \\
\hline \multirow[t]{6}{*}{2} & $\begin{array}{l}\text { Tim } \\
\text { Pengembang }\end{array}$ & $\begin{array}{l}\text { Perubahan objek } \\
\text { grafik pada scene } 5 \text {. }\end{array}$ & $\begin{array}{l}\text { Telah dilakukan } \\
\text { perubahan objek } \\
\text { grafik yang lebih } \\
\text { menarik dan } \\
\text { mudah dipahami } \\
\text { pada scene } 5 \text {. }\end{array}$ \\
\hline & & $\begin{array}{l}\text { Perubahan warna } \\
\text { gambar vektor uang } \\
\text { pada scene } \\
6 .\end{array}$ & $\begin{array}{l}\text { Telah dilakukan } \\
\text { perubahan warna } \\
\text { gambar vektor } \\
\text { uang pada scene } \\
6 .\end{array}$ \\
\hline & & $\begin{array}{l}\text { Perubahan pakaian } \\
\text { gambar vektor } \\
\text { karyawan pada scene } \\
7 .\end{array}$ & $\begin{array}{l}\text { Telah dilakukan } \\
\text { perubahan } \\
\text { pakaian seragam } \\
\text { gambar vektor } \\
\text { karyawan pada } \\
\text { scene } 7\end{array}$ \\
\hline & & $\begin{array}{l}\text { Penggambaran } \\
\text { bentuk cabai yang } \\
\text { kurang jelas, } \\
\text { sehingga tidak } \\
\text { terlihat perbedaan } \\
\text { antara ketiga cabai } \\
\text { pada scene } 8 \text {. }\end{array}$ & $\begin{array}{l}\text { Telah dilakukan } \\
\text { perbaikan bentuk } \\
\text { cabai yang lebih } \\
\text { realistis dan jelas } \\
\text { perbedaan antara } \\
\text { ketiga cabai pada } \\
\text { scene } 8\end{array}$ \\
\hline & & $\begin{array}{l}\text { Perubahan bentuk } \\
\text { gambar vektor rak } \\
\text { pengering pada scene } \\
10 .\end{array}$ & $\begin{array}{l}\text { Telah dilakukan } \\
\text { perbaikan bentuk } \\
\text { rak pengering } \\
\text { pada scene } 10 .\end{array}$ \\
\hline & & $\begin{array}{l}\text { Perubahan bentuk } \\
\text { gambar vektor } \\
\text { saringan pada scene } \\
11 .\end{array}$ & $\begin{array}{l}\text { Telah dilakukan } \\
\text { perbaikan bentuk } \\
\text { gambar vektor } \\
\text { saringan pada } \\
\text { scene } 11 \text {. }\end{array}$ \\
\hline
\end{tabular}

\section{Pengujian Beta}

Pengujian beta adalah pengujian yang dilakukan kepada target audience untuk melihat kualitas materi secara langsung dari konsumennya. Kualitas materi digunakan untuk mengetahui apakah informasi yang disampaikan dapat dipahami dengan baik atau tidak serta apakah dapat membuat masyarakat menjadi lebih mengetahuinya atau tidak [17]. Target audience diminta untuk melihat hasil produk motion graphic yang telah dibuat, kemudian mereka diminta untuk mengisi kuesioner penilaian terkait produk multimedia tersebut.

Pertanyaan pada kuesioner yang diajukan pada pengujian beta memiliki parameter penilaian yaitu penyajian informasi, visualisasi, audio, efek tambahan, dan tipografi. Selain itu, terdapat pertanyaan untuk mengukur pemilihan penyampaian informasi menggunakan media cetak atau menggunakan produk multimedia seperti motion graphic yang dapat disampaikan melalui media sosial. Daftar pertanyaan pada kuesioner dapat dilihat di Tabel 4.

\section{TABEL IV. DAFTAR PERTANYAAN KUESIONER PENGUJIAN}

\begin{tabular}{|c|c|}
\hline No & Pertanyaan \\
\hline 1 & $\begin{array}{l}\text { Apakah penyajian informasi dalam motion graphic ini } \\
\text { mudah dipahami? }\end{array}$ \\
\hline 2 & $\begin{array}{l}\text { Apakah komponen gambar yang digunakan pada motion } \\
\text { graphic ini berkualitas dan menarik? }\end{array}$ \\
\hline 3 & $\begin{array}{l}\text { Apakah suara yang digunakan sebagai komponen dalam } \\
\text { motion graphic ini tersampaikan dengan jelas? }\end{array}$ \\
\hline 4 & $\begin{array}{l}\text { Bagaimana kualitas dan keselarasan efek tambahan } \\
\text { berupa animasi transisi dan efek suara tambahan yang } \\
\text { digunakan sebagai penunjang motion graphic ini? }\end{array}$ \\
\hline 5 & $\begin{array}{l}\text { Apakah komponen tulisan (font) yang disampaikan telihat } \\
\text { jelas dalam menyampaikan informasi? }\end{array}$ \\
\hline 6 & $\begin{array}{l}\text { Jika harus memilih, media penyampaian informasi apakah } \\
\text { yang menarik buat Anda? } \\
\text { a. Media Cetak } \\
\text { b. Videografi } \\
\text { c. Animas (Motion Graphic) }\end{array}$ \\
\hline
\end{tabular}

3. Analisis Hasil Pengujian

Pengujian ini melibatkan 217 target audience sebagai responden dengan hasil penilaian yaitu untuk parameter konsep penyajian informasi $23,52 \%$ responden memilih sangat baik, $70,58 \%$ responden memilih baik, dan 5,90\% responden memilih sedang. Hasil penilaian visual/ penggambaran yaitu $41,18 \%$ responden memilih sangat baik dan $58,82 \%$ responden memilih baik. Penilaian audio yaitu 5,89\% responden memilih sangat baik, $41,17 \%$ responden memilih baik, dan 52,94\% responden memilih sedang. Penilaian efek yaitu $17,65 \%$ responden memilih sangat baik, $52,94 \%$ responden memilih baik, dan $29,41 \%$ responden memilih sedang. Penilaian tipografi yaitu 5,89\% responden memilih sangat baik, 64,70\% responden memilih baik, 23,52\% responden memilih sedang, dan $5,89 \%$ responden memilih kurang baik. Tabel 5 
menyajikan rekapitulasi presentase hasil pengujian produk multimedia. Gambar 2 menunjukkan hasil kepuasan terhadap setiap elemen pengujian. Grafik tersebut menunjukkan penilaian "Baik" menduduki level yang paling tinggi untuk setiap parameter yang diujikan. Presentase keberhasilan didapatkan dengan menjumlahkan rataan presentase perolehan sangat baik dan baik. Hasilnya menunjukkan presentasi kepuasan sebesar $76,45 \%$.

TABEL V. REKAPITULASI HASIL PENGUJIAN

\begin{tabular}{lrrrrr}
\hline $\begin{array}{c}\text { Parameter } \\
\text { Penilaian }\end{array}$ & $\begin{array}{c}\text { Sangat } \\
\text { Baik }\end{array}$ & Baik & Sedang & $\begin{array}{c}\text { Kurang } \\
\text { Baik }\end{array}$ & $\begin{array}{c}\text { Tidak } \\
\text { Baik }\end{array}$ \\
\hline Penyajian & 23,52 & 70,58 & 5,9 & 0 & 0 \\
Informasi & 41,18 & 58,82 & 0 & 0 & 0 \\
Visualisasi & 5,89 & 41,17 & 52,94 & 0 & 0 \\
$\begin{array}{l}\text { Audio } \\
\text { Efek }\end{array}$ & 17,56 & 52,94 & 29,41 & 0 & 0 \\
Tambahan & 5,89 & 64,70 & 23,52 & 5,89 & 0 \\
Tipografi & & & & & \\
\hline
\end{tabular}

Level Kepuasan Pada Pengujian Beta

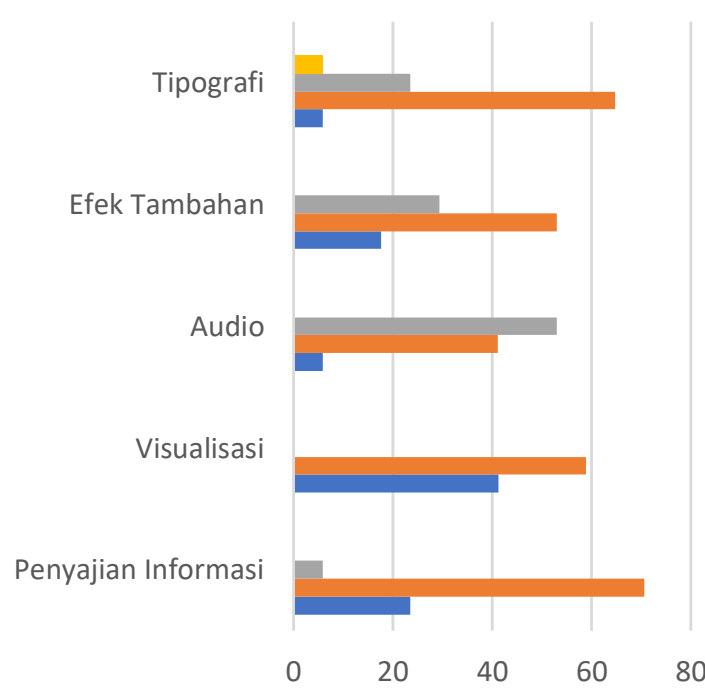

$$
\begin{array}{ll}
\text { - Tidak Baik } & \text { Kurang Baik } \square \text { Sedang } \\
\square \text { Baik } & \text { Sangat Baik }
\end{array}
$$

Gambar 2 Presentase Keberhasilan

Hasil pengujian beta yang sudah dilakukan dapat disimpulkan bahwa motion graphic ini layak ditampilkan dengan melakukan revisi terlebih dahulu. Penilaian responden terhadap komponen audio dan tipografi menunjukkan motion graphic memiliki kekurangan yang harus diperbaiki untuk penyempurnaan. Target audience yang telah melakukan pengisian kuesioner sebagian besar memilih animasi (motion graphic) sebagai media penyampaian informasi yang paling disukai. Sebanyak $78 \%$ responden memilih media tersebut. Selain itu, sebanyak $18 \%$ memilih videografi dan sisanya $4 \%$ memilih menyukai media cetak. Grafik hasil pemilihan media penyampaian informasi oleh responden di kalangan milenial dapat dilihat pada Gambar 3.

Pemilihan Media Informasi

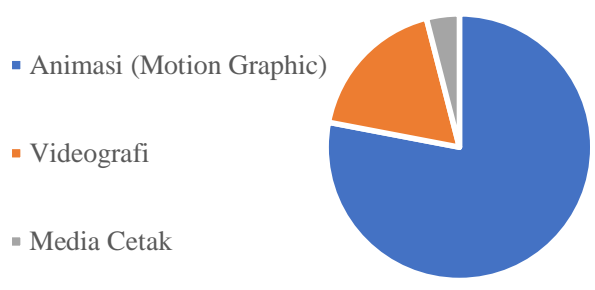

Gambar 3 Hasil Pemilihan Media Informasi

\section{F. Revisi}

Revisi adalah kegiatan memperbaiki kekurangan yang ditemukan saat proses pengujian. Komponen audio ditata ulang mulai dari perekaman ulang untuk pengisi suara sampai dengan menata ulang sound effect agar lebih selaras dengan gerakan animasinya. Revisi juga melakukan perbaikan pada komponen tulisan yang terdapat kesalahan ketik. Selain itu, revisi juga merapikan penataan komponen multimedia. Hasil revisi yang telah dilakukan kemudian dipresentasikan kembali kepada instansi BB Pascapanen dan siap untuk distribusi produk.

\section{G. Distribusi}

Proses distribusi produk adalah kegiatan menyerahkan produk kepada konsumen baik secara langsung maupun melalui perantara mitra kerjasama. Produk motion graphic yang telah dibuat diberikan kepada mitra kerjasama yaitu BB Pascapanen. Semua gambar vektor dan source hasil pengolahan gambar vektor dikumpulkan kemudian diberikan kepada bagian hubungan masyarakat di kantor BB Pascapanen. Penyebarluasan informasi dalam bentuk motion graphic ini direncanakan akan dilakukan melalui media sosial di lingkungan Kementerian Pertanian dan ditampilkan saat acara pameran maupun kegiatan-kegiatan instansi lainnya yang relevan dan memungkinkan untuk kegiatan sosialisasi. 


\section{KESIMPULAN DAN SARAN}

Pembuatan Motion Graphic Proses Penanganan Pascapanen dan Proses Teknologi Hasil Olahan Cabai telah berhasil diselesaikan. Kesimpulan dari hasil kegiatan ini adalah sebagai berikut:

1. Pembuatan motion graphic proses teknologi hasil olahan cabai yang telah berhasil diselesaikan memberikan informasi mengenai produk - produk hasil teknologi olahan cabai yang dimiliki oleh BB Pascapanen untuk dijadikan sebagai media sosialisasi kepada masyarakat khususnya generasi milenial. Produk digunakan untuk media sosialisasi di media sosial. Durasi dari produk yang dihasilkan adalah 2 menit 37 detik.

2. Berdasarkan hasil pengujian produk terhadap target audience menunjukkan bahwa konsep penyajian informasi menggunakan motion graphic yang telah dibuat secara keseluruhan dapat diterima dengan baik. Terdapat 5 parameter pada pengujian beta yaitu penyajian informasi, visualisasi, audio, efek, dan tipografi. Hasil analisis kepuasan dalam penggunaan produk menunjukkan penilaian "Baik" menduduki level yang paling tinggi disusul dengan sedang dan sangat baik, untuk setiap parameter yang diujikan. Presentase kepuasan yang didapatkan sebesar 76,45\%. Permasalahan yang muncul setelah pengujian telah ditindaklanjuti untuk dilakukan perbaikanperbaikan agar meningkatkan kepuasan.

3. Media penyampaian informasi terkait penanganan pascapanen dan teknologi hasil olahan cabai menggunakan animasi motion graphic menjadi pilihan masyarakat di kalangan milenial.

4. Produk motion graphic yang telah direvisi sudah didistribusikan kepada mitra kerjasama untuk nantinya dapat dijadikan sebagai media penyebaran informasi khususnya disebarluaskan pada media sosial.

Penelitian ini merupakan kegiatan implementasi atau terapan yang manfaatnya langsung dapat dirasakan oleh masyarakat. Sosialisasi melalui media sosial menjadi salah satu pilihan dikarenakan penduduk Indonesia khususnya kalangan milenial banyak menggunakan media tersebut. Oleh karena itu, sosialisasi atau edukasi kepada masyarakat perlu difasilitasi dengan media informasi berbasis multimedia.

Efektivitas dalam penyampaian informasi menggunakan produk multimedia yaitu motion graphic akan lebih optimal lagi ketika dapat dipastikan informasinya diterima oleh konsumen dan tepat sasaran. Untuk memastikan ketersampaian informasi tersebut, perlu adanya tindak lanjut yaitu menciptakan adanya interaktivitas dari target audience. Jadi, media informasi tidak sekedar disebarluaskan tetapi juga ada aksi timbal balik yang bisa dipicu dengan kegiatan pemberian hadiah (give away) untuk komentar terbaik, ajakan untuk menyukai konten (like), dan ajakan untuk menandai teman-teman sesamanya melalui tag. Dengan interaktivitas yang diupayakan tersebut, informasi yang disebarluaskan akan berjalan lebih optimal.

\section{REFERENSI}

[1] R. Suryani, H. Saputra, and A. Sutrisman, "Implementasi Animasi 2D pada Iklan Layanan Masyarakat sebagai Sosialisasi Penyakit DBD," Rekam, vol. 15, no. 2, pp. 153-166, 2019, doi: 10.24821/rekam.v15i2.3330.

[2] R. Tamami, "Pemanfaatan Media Pembelajaran Interaktif (MPI) Powerpoint Untuk Visualisasi Konsep Menggambar Grafik Persamaan Garis Lurus," J. Math. Educ., vol. I, no. 1, pp. 1-12, 2014.

[3] N. Nurfajry, H. Saputra, and E. Laila, "Penerapan Media Pembelajaran Audio-Visual tentang Peningkatan Sesamol sebagai Zat Penghambat Pertumbuhan Sel Kanker menggunakan Teknik Motion Graphic," Multinetics, vol. 5 , no. 2, pp. 30-38, 2019, doi: 10.32722/multinetics.v5i2.2407.

[4] Munir., Multimedia Konsep dan Aplikasi dalam Pendidikan. Bandung: Alphabet, 2012.

[5] Y. Anggraini, C. Antoni, and S. Prasetyaningsih, "Analisis dan Implementasi Motion Grafis Iklan Layanan Masyarakat (ILM) dengan Metode Semiotika Peirce," $J$. Ilmu Komun., vol. 1, no. 1, pp. 64-82, 2018.

[6] M. Stickdorn, M. Hormess, A. Lawrence, and J. Schneider, This Is Service Design Doing: applying service design thinking in the real world (a practitioner's handbook). California: O'Reilly Media, Inc, 2018.

[7] Rahayu, "Desain Multimedia," Malang: Direktorat Pembinaan Sekolah Menengah Kejuruan, 2013.

[8] I. Binanto, Multimedia Digital - Dasar Teori dan Pengembangannya. Yogyakarta: CV Andi Offset, 2010.

[9] A. Saputra, "Pembuatan Motio Graphic Sebagai Media Promosi untuk Proyek Purna Jual Datsun Sigap," J. Ilm. Manaj. Inform. dan Komput., vol. 2, no. 2, pp. 84-97, 2018.

[10] A. Suandi, K. Nidaul, and E. Retnoningsih, "Pengujian Sistem Informasi E-commerce Usaha Gudang Cokelat Menggunakan Uji Alpha dan Beta," Inf. Syst. Educ. Prof., vol. 2, no. 1, pp. 61-70, 2017.

[11] N. A. Busroh, "Pembuatan Company Profile sebagai Media Promosi Tuju semesta Creative Space,” IPB, Bogor, 2017.

[12] V. Kharishma, R. Firnandi, M. Iqbal, and E. D. Krishnasari, "Perancangan Motion Graphic Untuk Iklan Layanan Masyarakat Berjudul Go Green Dengan Rumah Ekologis," Pros. Semin. Nas. Teknol. Inf. dan Multimed., vol. 1, no. 1, pp. 1-6, 2018.

[13] D. Phetorant, "Peran Musik dalam Film Score," J. Music Sci. Technol. Ind., vol. 3, no. 1, pp. 91-102, 2020, doi: 10.31091/jomsti.v3i1.967.

[14] H. Anisyah, H. Saputra, and M. Mustaziri, "Penerapan Video Animasi Motion Graphic Tentang Pembuatan Kartu Identitas Anak di Kec.Sukarami," Multinetics, vol. 5, no. 
2, pp. 39-45, 2019, doi: 10.32722/multinetics.v5i2.2437.

[15] A. P. Nugroho and E. T. Luthfi, "Implementasi teknik voice over dan sound effect dalam pembuatan film pendek 'arah' naskah publikasi," AMIKOM Yogyakarta, 2017.

[16] A. Muslim, Kreasi Animasi Menggunakan Adobe After Effects. Yogyakarta: CV Andi Offset, 2017.

[17] A. F. 'Aini, "Pengembangan Media Pembelajaran Berbasis Multimedia Interaktif Dalam Pelajaran Hukum Tajwid," Multinetics, vol. 7 , no. 1, pp. 1-11, 2021, doi: 10.32722/multinetics.v7i1.3477. 